\title{
PTK2B wt Allele
}

National Cancer Institute

\section{Source}

National Cancer Institute. PTK2B wt Allele. NCI Thesaurus. Code C51107.

Human PT K2B wild-type allele is located in the vicinity of 8p21.1 and is approximately 148 $\mathrm{kb}$ in length. This allele, which encodes protein tyrosine kinase 2 beta protein, plays a role in both the calcium-dependent regulation of ion channels and activation of the map kinase signaling pathway. 